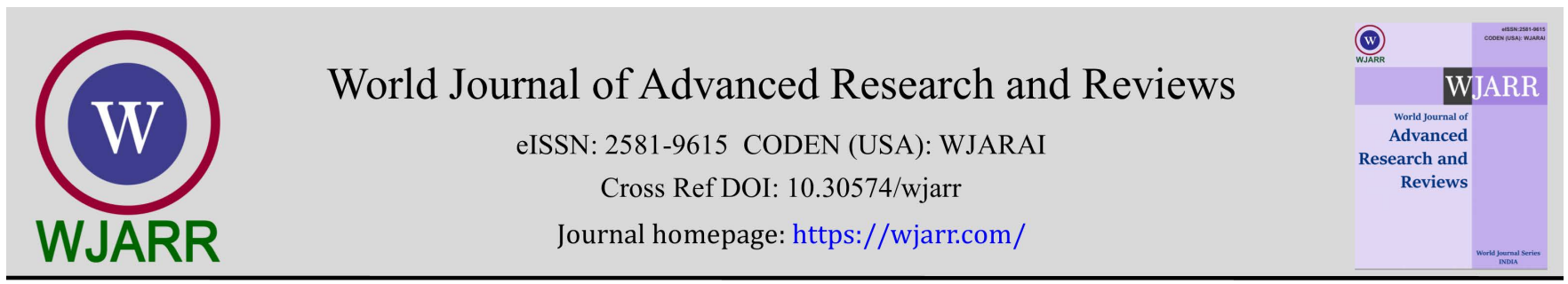

(RESEARCH ARTiClE)

\title{
Manifestations of climate variability in the department of Alibori in Benin
}

\author{
Aristide Lantokpodé $2,{ }^{*}$, Ayokpon Hondo Nicolas ${ }^{3}$, Rodrigue C Rodrigue ${ }^{1}$ and Ibourahim Yabi ${ }^{2}$ \\ ${ }^{1}$ Department of Geography and Regional Planning (Univertsity of Abomey-Calavi). \\ ${ }^{2}$ Pierre Pagney Laboratory of Climatology of the University of Abomey-Calavi. \\ 3 Institut Régional de Santé Publique (IRSP/UAC).
}

World Journal of Advanced Research and Reviews, 2022, 13(01), 679-688

Publication history: Received on 06 November 2021; revised on 20 January 2022; accepted on 22 January 2022

Article DOI: https://doi.org/10.30574/wjarr.2022.13.1.0590

\begin{abstract}
The manifestations of climate variability are a major problem for all communities around the world and particularly for the populations of the Department of Alibori in northern Benin. This study aims to characterize the manifestations of climate variability in the Alibori department in the north of the Republic of Benin. Thus, climatic data such as rainfall, air temperature and relative air humidity were collected from the national meteorological service. These data were analyzed using descriptive statistics (mean values) and graphical representations. The results obtained reveal that over the period 1961 to 2020 , the average temperature varies between $25^{\circ} \mathrm{C}$ in January to $33^{\circ} \mathrm{C}$ in April. Year-to-year variations in air temperature show that air temperature is rising steadily over the period 1961-2020. Higher than average values were recorded from 1985. Relative humidity remained in excess (above 55\% which is the interannual average) from 1960 to 1982 and in deficit after 1982 (humidity below 55\%). The bioclimatic comfort is most felt during the months of May, November, April and March over the period 1971-2015. This sensation is mainly felt in the morning (from 6 to 9 hours).
\end{abstract}

Keywords: Manifestations; Climate variability; Alibori Department; Communities

\section{Introduction}

Because of their immediate and lasting repercussions on the natural environment and on humans, questions of climate change and variability have for some time been placed at the center of the concerns of scientists and political decisionmakers around the world [1]. In recent years, climate change and recurrent food crises have undermined the achievement of the Sustainable Development Goals (MDGs) [2]. Their economic, human and social consequences primarily affect vulnerable populations. Between December 2011 and March 2012, world food prices increased by 8\%, increasing the risk of food insecurity for the populations of countries importing these goods (according to the Food Price Watch Report of the World Bank, April 2012) [3]. In 2010, climate change-related disasters affected around 300 million people and displaced 40 million people, mostly in developing countries.

Characterizing the impact of climate variability on seasonal rainfall patterns then becomes essential in order to offer solutions adapted to development projects and the preservation of the health of populations. The variability of climatic conditions in West Africa in general and in Benin in particular, is well established. in Benin, it first affected the north, then gradually spread to the center and finally to the coast. These rainfall anomalies observed for nearly four decades have had an exceptional resonance in the northern and central regions of the country. But in reality, the whole country is highly vulnerable to rainfall deficits. Climate variability as a phenomenon has long been studied and characterized. The most important question, both for West Africa and in other parts of the world, is the search for explanatory factors. Most of the climate studies carried out were limited to the analysis of annual or monthly rainfall data. Also, variables

\footnotetext{
* Corresponding author: Aristide Lantokpodé

Department of Geography and Regional Planning (Univertsity of Abomey-Calavi).

Copyright $(2022$ Author(s) retain the copyright of this article. This article is published under the terms of the Creative Commons Attribution Liscense 4.0.
} 
relating to rainfall, such as the frequency of rainy days and the length of the rainy seasons, have generally been very little studied. This could be justified by the difficulty in acquiring daily measurement data, reliable and with few gaps. Thus during this study, it will be attempted to analyze climatic parameters such as air temperature, relative air humidity and the frequency of rainy days and study their impact on the variability of the precipitation regime.

This study therefore proposes to investigate the influence of the climatic manifestation in the Department of Alibori in northern Benin.

\section{Framework, material and study method}

\subsection{Study framework}

In 2013, the department of Alibori had 867,463 inhabitants, or 8.7\% of the Beninese population. The intercensal growth rate of $4.61 \%$ is higher than the national average. In the department of Alibori, out of 1,000 children born alive 112 die before reaching their fifth birthday in 2013. The mortality of children under five is higher in the towns of Karimama (219 per thousand) and Malanville ( 148 per thousand). As for the mortality before the first birthday, it affects 70 children out of 1000 in the department of Alibori. The level of mortality is higher in rural areas than in urban areas. The mortality quotient for children under five is 113 per thousand in rural areas and 107 per thousand in urban areas.

\subsection{Material and study method}

\subsubsection{Study data}

The climatic data used in this study are rainfall, air temperature and relative air humidity. They were collected from the national meteorological service. Daily rainfall, temperatures and relative air humidity at Kandi and Natiting ou stations cover the period 1990-2021 (Figure 2). These data are fairly homogeneous, of good quality and representative of the study area. The data used were used to study climate variability over time and space and its impact on seasonal weather patterns in the Alibori Department.

\subsubsection{Methods of studying climate variability}

Analysis of air temperature and relative humidity

The air temperature and relative air humidity of Alibori Department were analyzed using descriptive statistics (mean values) and graphical representations. This analysis was carried out from synoptic stations and helped to understand the seasonal and interannual variation in temperature and relative humidity of the air in the Alibori Department.

\section{Mapping of rainfall indices}

In order to assess the evolution of rainfall over different years, the rainfall index method was applied. This method has the advantage of highlighting periods of surplus and deficit. Thus, for each of the pluviometric stations selected, an interannual rainfall index was determined. It is defined as a reduced centered variable expressed by equation 1 (Servat et al., 1998)

$$
I=\frac{x i-X}{S}
$$

With

$\mathrm{xi}$ : annual rainfall value for year $\mathrm{i}$;

$\mathrm{X}$ : interannual average value of rainfall over the period studied;

S: interannual value of the standard deviation of rainfall over the period studied.

The cartographic representation of interannual rainfall indices, calculated by decade over the period 1990-2020, reflects the spatial evolution of the reduced centered variable studied while highlighting areas that are sometimes in deficit, sometimes in surplus. This mapping was carried out using the Surfer software.

\section{Rainy day analysis}

The study of the variability of the annual number of rainy days has received little attention in previous work (Servat et al., 1998). From a climatological point of view, however, the study of rainy days can help to improve knowledge on aspects of seasonal and annual rainfall deficits as well as on the changes likely to affect the evolution of precipitation. 
Indeed, these deficits can result from the decrease in the frequency of heavy precipitation having reached or exceeded a certain threshold. From a sanitary and hydrological point of view, the decrease in the frequency of heavy rains and the distribution of rains within the season are important data. They must be taken into account in the modeling of the variation in the soil moisture content, in the setting of the drainage structures for runoff and irrigation water, in the determination of the laying period and the hatching of the eggs. Culicidae vectors of diseases and other pathological germs as well as in models for predicting river floods. Thus, a characterization of rainfall regimes cannot be limited to a simple statistical analysis of rainfall accumulations. It must also include the frequencies of rainy days. In fact, rain is not a continuous phenomenon. Precipitation occurs during rainfall events of varying durations following one another at varying intervals of time. This intermittence is particularly important in West Africa.

The typology of daily precipitation that has been proposed is linked to the international threshold standards defined by the World Meteorological Organization (WMO, 1990). The different classes are defined according to the number of rainy days of height between:

- $\quad 1$ et $10 \mathrm{~mm}\left(\mathrm{P}_{1}\right)$;

- 10 et $30 \mathrm{~mm}\left(\mathrm{P}_{2}\right)$;

- 30 et $50 \mathrm{~mm}\left(\mathrm{P}_{3}\right)$;

- $\quad>50 \mathrm{~mm}\left(\mathrm{P}_{4}\right)$.

The number of rainy days (variable relating to rain) was studied on an interannual scale.

Hubert's segmentation method, widely used in the study of climate variability for its performance and robustness (Lubès-Niel et al., 1998), was applied to identify breaks within time series of frequencies. rain (Patutel et al., 1998; Servat et al., 1998; Ardoin, 2004; Kouassi, 2007).

\section{Results and discussion}

\subsection{Variations in temperature and relative humidity of the air}

\subsubsection{Variations in air temperature}

The average air temperature values for the period 1990-2020 shown in Table I allow the average change in the thermal regime to be followed at the Department of Alibori level.

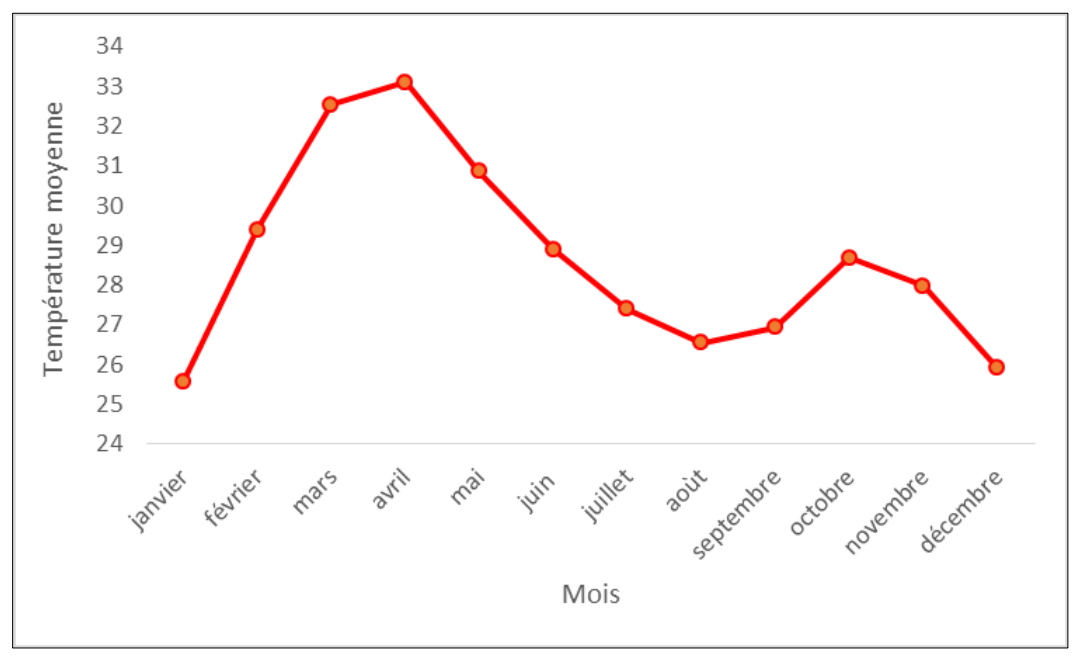

Figure 1 Monthly temperatures at KANDI stations (1961-2020)

Average monthly temperatures at Kandi station vary between $25.54{ }^{\circ} \mathrm{C}$ (January) and $33.1^{\circ} \mathrm{C}$ (April). The maximum monthly averages are generally observed during the months of March and April. Temperatures are generally high, but vary little throughout the year.

The year-to-year variations in air temperature show that the air temperature is increasing steadily over the period 1961-2020. 


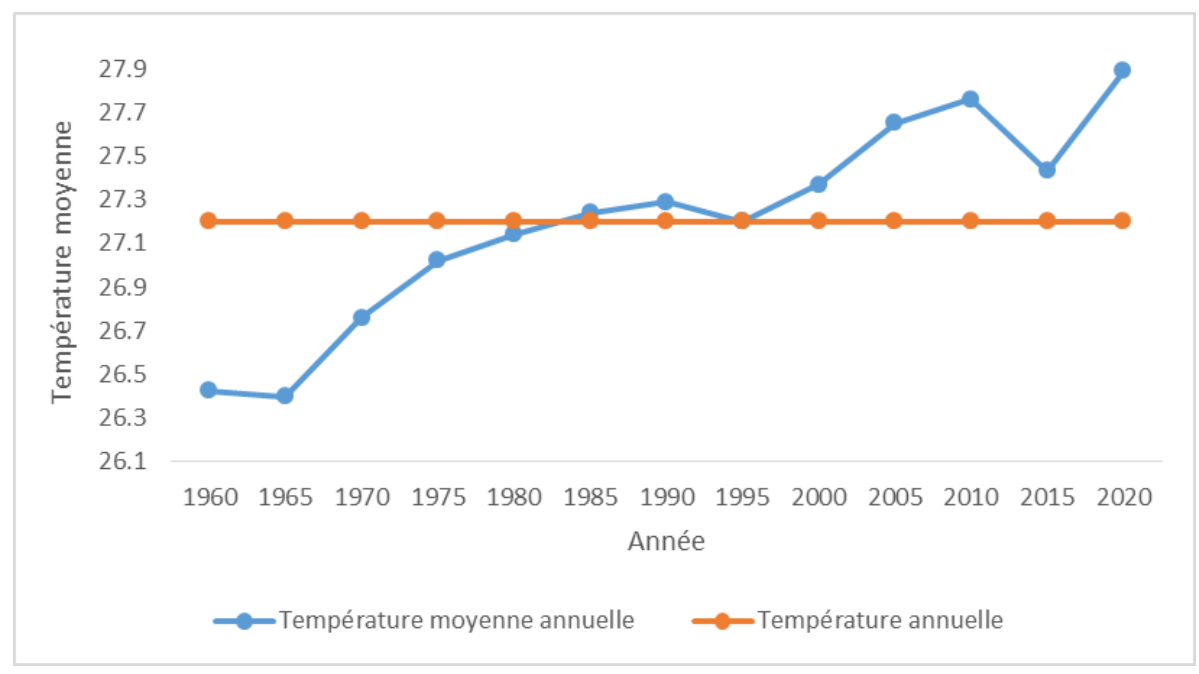

Figure 2 Interannual variations in air temperature (1961-2020): in Kandi

We can therefore see that it is getting hotter in the study environment. Higher than average values were recorded from 1985. This trend was accentuated from the $2000 \mathrm{~s}$ with temperatures above $27.5^{\circ} \mathrm{C}$ on average.

\subsubsection{Variations in relative air humidity}

Relative humidity is expressed as a percentage and is defined as the ratio of the amount of water actually contained in the air and the absorption capacity at a given temperature. The monthly mean relative humidities (1960-2020) at Kandi (figure) vary between $28.54 \%$ (February) and $81.31 \%$ (August). The monthly mean relative humidities (1960-2020) oscillate between $66.7 \%$ (January) and $79.3 \%$ (August) at the Kandi station. Relative humidity is generally above $70 \%$ and varies relatively widely throughout the year.

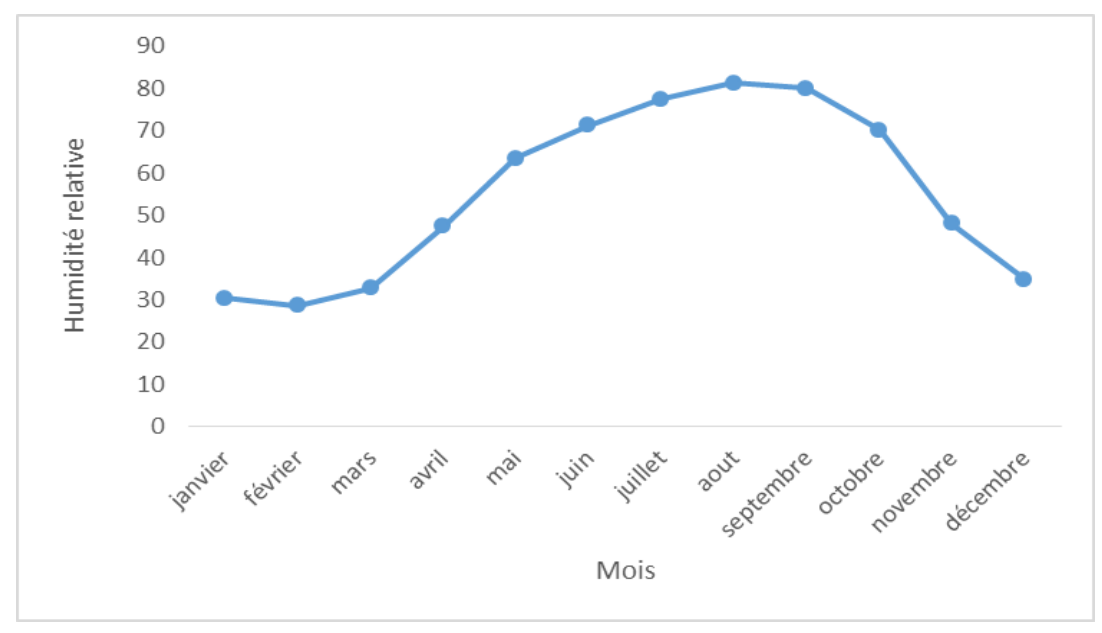

Figure 3 Average monthly relative humidity (\%) at Kandi stations (1960-2020)

The interannual variations in relative humidity over the period 1960-2020 show that in the department of Alibori (Figure 3), the relative humidity remained in excess (greater than 55\% which is the interannual average) from 1960 to 1982 and deficit after 1982 (humidity less than 55\%). 


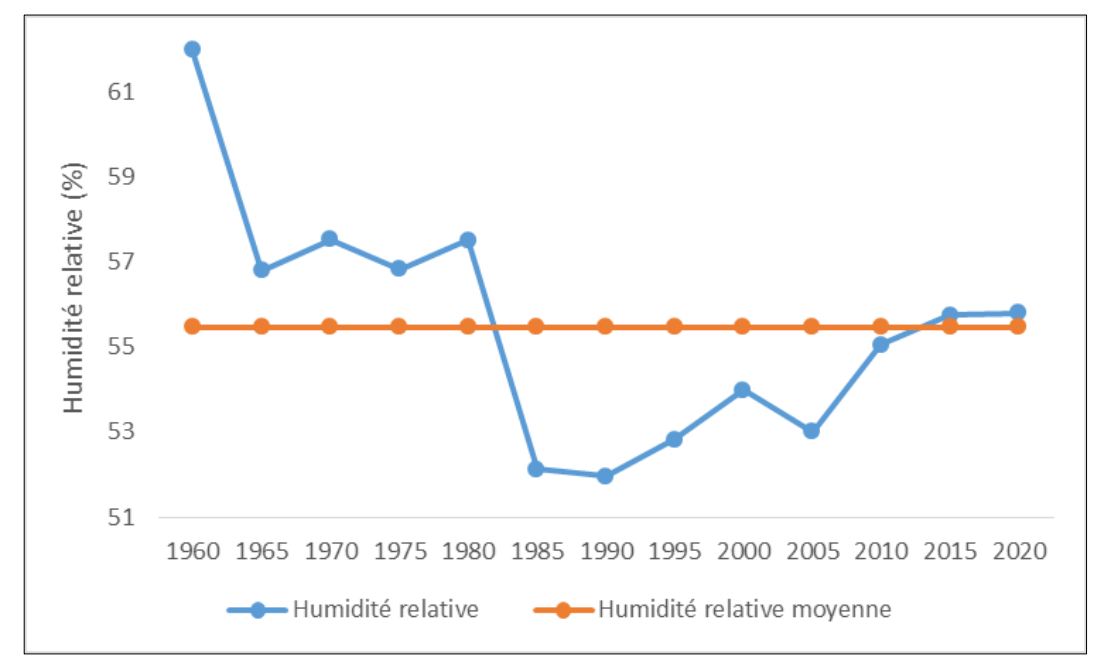

Figure 4 Interannual variations in relative air humidity from 1960 to 2020 in Kandi

\subsubsection{Evolution of climatic atmospheres in the Department of Ouémé}

The bioclimatic atmospheres were determined by means of the indices of THI, K and UTCI. The results obtained from these calculations are presented in three phases, namely: the environments described by the THI, the environments described by the K and the environments described by the UTCI.

Atmospheres described by the cooling power of the air (K)

The figure 5 shows the atmospheres described by the index K.

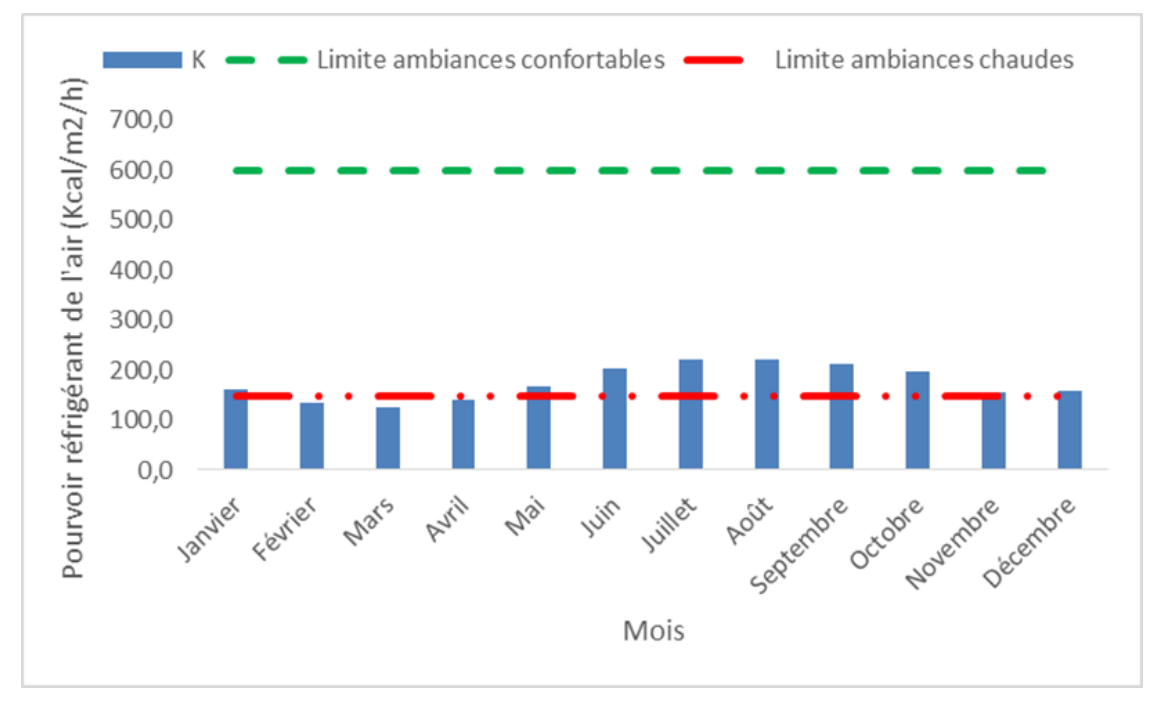

Figure 5 Inter-monthly evolution of the cooling capacity of the air from 1960 to 2020; (Data source: ASECNA (2020))

Analysis of the figure shows that the values of K oscillate between $125 \mathrm{kcal} / \mathrm{m}^{2} / \mathrm{h}$ and $221 \mathrm{kcal} / \mathrm{m}^{2} / \mathrm{h}$. From January to March on the one hand and from November to December on the other hand, the average values of $\mathrm{k}$ are around 80 $\mathrm{kcal} / \mathrm{m}^{2} / \mathrm{h}$. From April to October, the cooling capacity of the air sometimes reaches $154 \mathrm{kcal} / \mathrm{m}^{2} / \mathrm{h}$.

In January, the thermal environment is generally moderate and characterized by hot weather. The month of February is characterized by a moderate warm atmosphere (hypotonic) with a slight evolution towards a very hot (atonic) atmosphere. The months of March are found in a warm atmosphere generally moderate but hotter than the months of February.

During the month of April, the weather is slightly warmer than in March and the k values hover around $140 \mathrm{kcal} / \mathrm{m} 2$ / h. The month of May is characterized by a slight comfort with $166 \mathrm{Kcal} / \mathrm{m} 2 / \mathrm{h}$. The situation is almost identical during 
the months of June to October with $\mathrm{K}$ values above $149 \mathrm{Kcal} / \mathrm{m} 2 / \mathrm{h}$. These months are more or less relaxing ie hypotonic. During the months of November to January, the values of k are at the limit of discomfort, at $149 \mathrm{Kcal} / \mathrm{m} 2$ / h.

In the Department of Alibori, according to the values of $\mathrm{K}$, the months with generally acceptable moods are the months of May to October. July and August seem to be the most comfortable. The populations of this environment live for half of the year in an uncomfortable atmosphere, which weakens their state of health.

\subsection{Bioclimatic environments described by the THI}

The figure 6 shows the atmospheres described by the THI index.

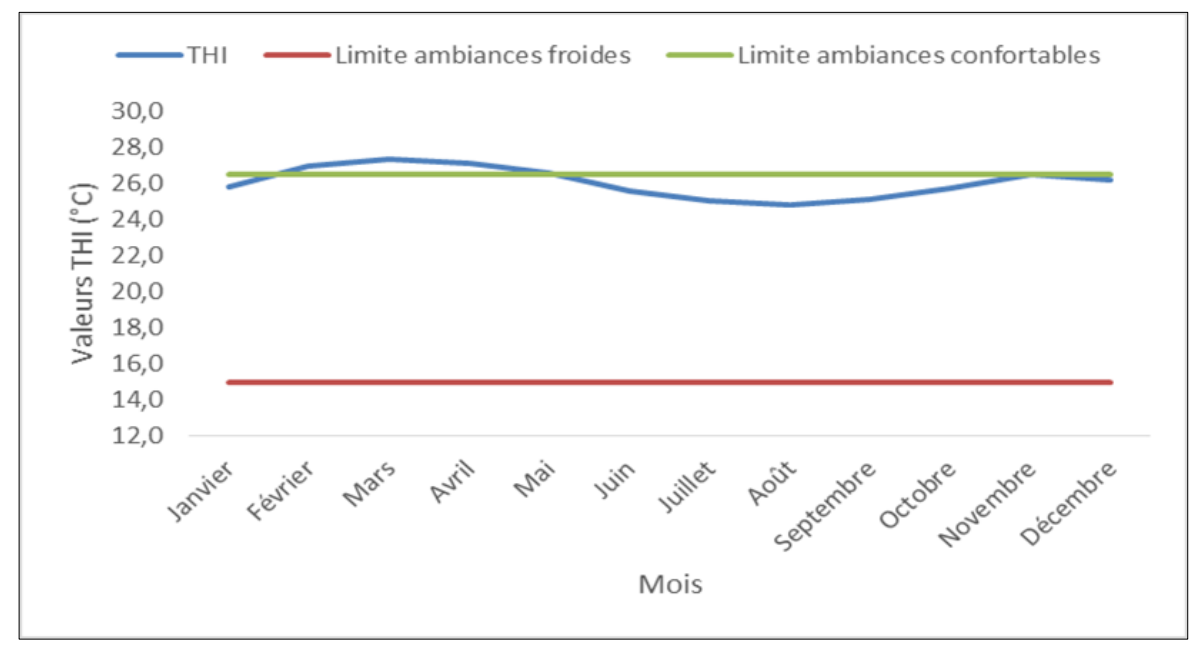

Figure 6 Inter-monthly evolution of the thermohygrometric index from 1960 to 2020; (Data source: ASECNA (2020))

Analysis of the figure shows that the Thermo-hygrometric index varies between the values $25^{\circ} \mathrm{C}$ and $28^{\circ} \mathrm{C}$. In January, the thermohygrometric atmosphere is characterized by an overall favorable atmosphere $\left(25^{\circ} \mathrm{C}\right)$. The months of February to May are characterized by a very hot atmosphere.

During the months of June to October, the weather is more comfortable with THI values oscillating between 25 and 26 ${ }^{\circ} \mathrm{C}$. The atmospheres of these months do not trigger the mechanisms of thermogenesis and thermolysis. From November to December, the thermohygrometric atmosphere becomes slightly uncomfortable again with THI values of 26.5 and $26.2^{\circ} \mathrm{C}$.

In short, only five (5) out of twelve (12) months experience a comfortable bioclimatic atmosphere for the populations in the Department of Alibori.

Bioclimatic atmospheres described by UTCI

The figure 7 shows the atmospheres described by UTCI $\left({ }^{\circ} \mathrm{C}\right)$.

From an examination of the average values of UTCI over the period 1960-2020, it appears that not all months are characterized by a "no stress" atmosphere.

So in January, the feel of the UTCI vibe is in the discomfort zone. This period is characterized by strong heat, and this is so until March-April. It should be noted that this sensation is important in the morning of January and February. These months are characterized by a dry season and especially by the harmattan. From May to October, the sensations are essentially and only "no stress". This period corresponds to the great rainy season and the short dry season. Towards the end of the year, that is, from November to December, the atmosphere becomes slightly uncomfortable again.

In sums every month is not characterized by an uncomfortable bioclimatic atmosphere. The dry season months (January, February, November and December) were dominated by an uncomfortable atmosphere, while during all the rainy months, the bioclimatic atmospheres are more generally "comfortable" mode. 


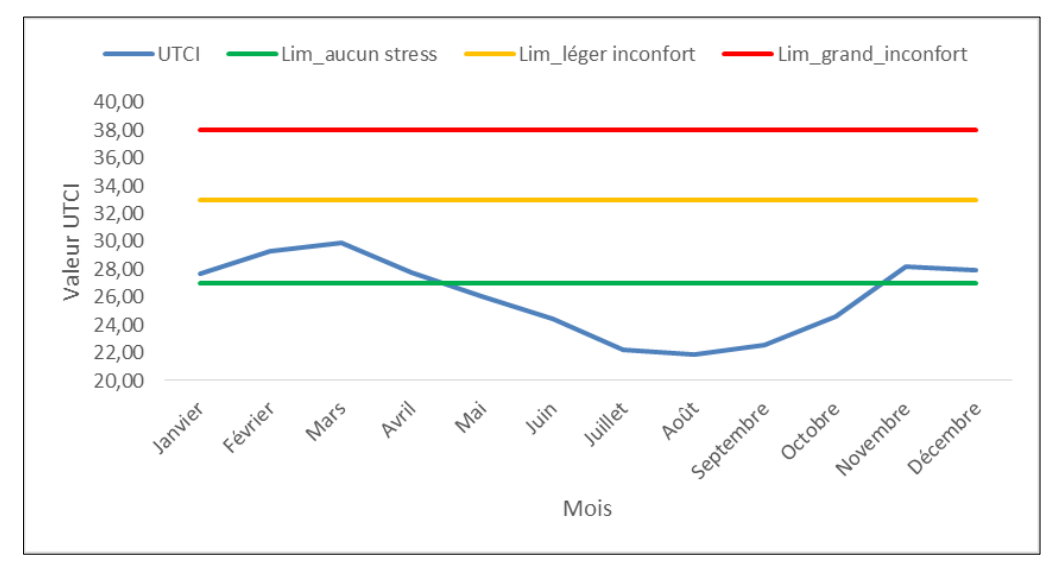

Figure 7 Inter-monthly evolution of the UTCI from 1960 to 2020; (Data source: ASECNA (2020))

\subsection{Summary of bioclimatic atmospheres}

The figure 8 presents the synthesis of bioclimatic atmospheres estimated from K, THI and UTCI in the Department of Alibori.

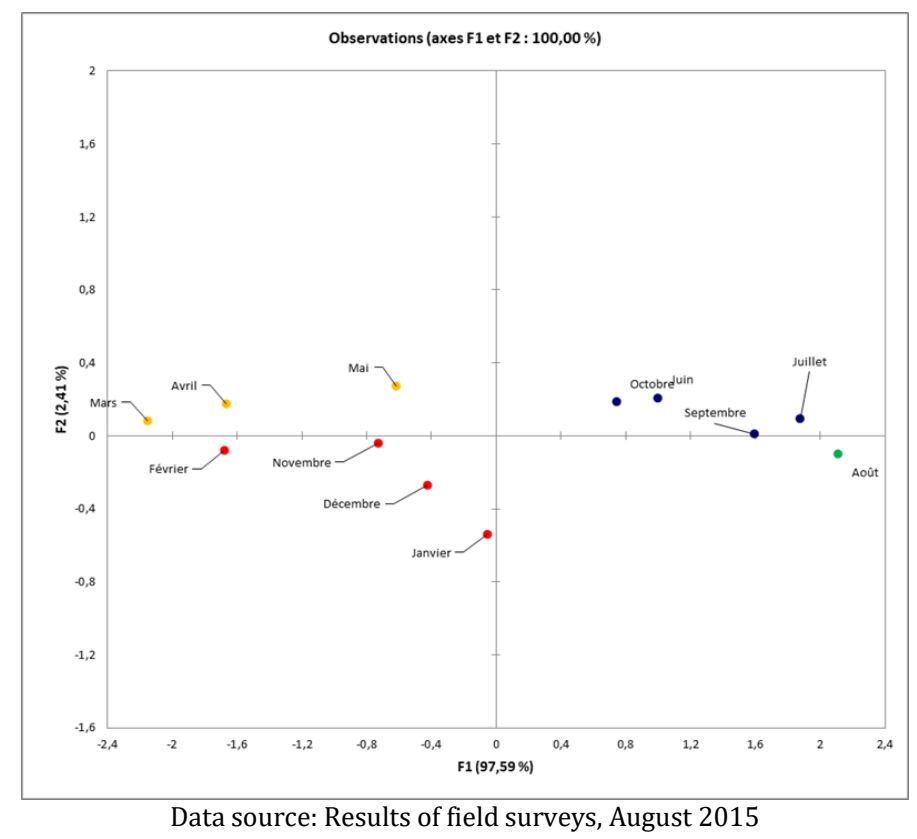

Figure 8 Summary of atmospheres described by K, THI and UTCI

Legend:: Comfort: Slightly taxing: Challenging: Very trying

Analysis of the figure makes it possible to distinguish four (4) categories of bioclimatic environments in the Atlantic Department. In the first category, we can conclude that the bioclimatic comfort is more felt during the months of May, November, April and March over the period 1971-2015. This sensation is mainly felt in the morning (from 6 to 9 hours).

In the second category, we notice that the bioclimatic environments become slightly trying during the months of December and February.

The months of June, July, August, October and September are characterized by a more trying atmosphere than in the previous category (especially around 12 o'clock). Finally, from a statistical and bioclimatic point of view, in January (last category), the bioclimatic atmosphere experienced is the most trying (between 3 p.m. and 6 p.m.).

We can remember that whatever the category, the bioclimatic environments are not trying throughout the month and even less throughout a day (in general) or a month. 


\section{Discussion}

The mapping of rainfall indices in the department of Alibori made it possible to highlight the general downward trend in rainfall from the decade 1961-1970, which worsened over the following decades. However, the entire study environment was not affected in the same way given the influence of local climates (subtropical climate in the North, equatorial climate in the South, influence of the two types of climate in the center of the basin). This result is in agreement with the results of statistical tests applied to annual rainfall (Goula et al., 2006; Kouassi et al., 2008). This climatic variability is manifested by a drop in relative humidity and an increase in air temperatures, which results in an affection of the hydrological cycle in general and the formation of pluviogenic clouds in particular, hence the weakness of annual rainfall levels. In tropical forest regions where forest surfaces are very extensive and sensitive to surface conditions, and where atmospheric humidity has a marked continental origin (Fontaine and Janicot, 1993), the increase in dry surfaces must cause an increase in temperatures. of air by heat transfer. The reduction in forest cover, which naturally absorbs carbon dioxide contained in the atmosphere, will contribute to increasing the atmospheric content of this greenhouse gas (Sultan et al., 2001). Hubert's segmentation procedure allowed to highlight the reality of a significant drop in the frequency of rainy days in the N'zi (Bandama) catchment area from the end of the 1970s. The climatic variability observed in the N'zi basin is linked partly to the decrease in the frequency of rainy days in general and to daily rains with a rainfall of between 10 and $50 \mathrm{~mm}$ in particular. Indeed, the decrease in the frequency of rainy days is synchronous with that of the annual rainfall (Kouassi et al., 2008). The work of Paturel et al. (1998) and Servat et al. (1998), showed that the number of rainy days has decreased in West Africa while it seems to be more stable over Central Africa. This climatic parameter (number of rainy days) seems to have decreased from the 1970s onwards. Countries such as Senegal, Mali, Burkina Faso and Chad, as well as the forest areas of Guinea and Côte d'Ivoire , are the first to be affected by this phenomenon (Servat et al., 1998). During the 1980s, it intensified and then affected Benin. More locally, Houndenou and Hernandez (1998) have shown that the Atakora region is facing a general decrease in the number of rainy days over the 1961-1990 period which started from 1963-1964 and became persistent after 1968. For these authors, the drop in rainfall after 1970 is partly due only to a decrease in the number of rainfall events during the rainy season. By studying the evolution of the chronological series of 33 rainfall stations in West Africa in the Sahelian zone spread over Senegal, Mali, Burkina Faso and Niger, Hubert et al. (1989) highlighted large breaks located most of the time between 1968 and 1969 in the series of annual number of rainy days (Ouédraogo, 2001). These breaks also corresponded to a decrease in this variable. The change observed in the cumulative rainfall amounts was accompanied by a change in the duration of the rainy seasons. In fact, the start of the rainy seasons has been delayed, the duration of which varies from one region to another and an early end. A tendency to shorten the rainy seasons is therefore highlighted in the N'zi watershed (30-35 days). Houndenou and Hernandez (1998) reached the same conclusion in a similar study carried out in Benin (West Africa). According to Ouédraogo (2001), Adefolalu (1986) noted a delay of at least 25 days in the start of the rainy seasons in the Sudano-Sahelian zone of Nigeria during the 1983 drought which, let us remember, is an extreme year. This delay even reaches 40 to 50 days in some parts of Nigeria during the same year. Adejuwon et al. (1990) also describe a delay in the start of the rainy seasons and an early end of the rainy season based on the study of a few stations spread over different climatic zones of Nigeria (Ouédraogo, 2001).

According to the work of Servat et al. (1998) in West and Central Africa, the changes that can be observed are not very clear: the rainy season tends to last less than before. However, it is difficult to clearly determine whether it now starts later or whether it ends earlier. For the few countries bordering the Gulf of Guinea and experiencing a two-season rainy regime, the results are again unclear. Nevertheless, a trend towards shorter rainy seasons seems to be emerging. More precisely, in Côte d'Ivoire, the second rainy season has a shorter duration than before, the first rainy season is experiencing the same trend, but to a lesser extent; in Togo as in Benin, the shortening of the duration mainly affects the first rainy season; in Cameroon, it is the other way around. The dates of occurrence of these phenomena are very different from country to country, from post to post. The N'zi watershed is experiencing a change in the duration of the rainy seasons regardless of the climatic zone. However, the seasonal rainfall patterns defining weather patterns have not changed. Indeed, the northern part still has only one rainy season and one dry season. The central and southern parts have at their level two (2) rainy seasons and two (2) dry seasons.

It appears that the temperature and relative humidity of the air are factors in the temporal variability of seasonal rainfall regimes in the N'zi watershed. Indeed, these atmospheric parameters strongly influence the temporal variability of rainfall variables. However, the previous results of the study show a decrease in rainfall variables as well as relative humidity and an increase in temperatures over the past decades in the N'zi (Bandama) watershed. Based on these findings, we can say that the variability of seasonal rainfall patterns depends on the one hand on the drop in relative humidity and on the other hand on the increase in air temperature. The contribution of our study is the use of several variables based exclusively on precipitation and on atmospheric parameters (temperature and relative humidity of the air) to analyze seasonal rainfall patterns and determine the factors of their temporal variability. With a view to rising air temperature, we have every reason to fear a change in seasonal weather patterns in the N'zi watershed. The results 
obtained can be linked to other work around the world. Based on the results of the work of Richard et al. (2002), during the 20th century, the frequency of ENSO-LNSO events is positively correlated with global temperature (Wang and Ropelewski, 1995 in Richard et al., 2002) and their intensity is maximum over the period after 1970 (Wang and Wang, 1996 in Richard et al., 2002). At the same time, in southern Africa, their effect on rainfall has increased (Richard et al., 2000 in Richard et al., 2002) and droughts have become more pronounced and widespread in space (Richard et al. ., 2001 in Richard et al., 2002). These results can be related to the increase in the magnitude of the variations described around 1970.

\section{Conclusion}

This study characterized the main manifestations of climate variability in the Department of Alibori. Monthly relative humidity ranges from 52.2\% (January) to 82.5\% (August) with an average of 73.4\%. The analysis of interannual variations in relative humidity shows a decrease in relative humidity since 1973 . The average monthly temperatures vary between $23.6^{\circ} \mathrm{C}$ (August) and $28.5^{\circ} \mathrm{C}$ (February) with an average of $26.2^{\circ} \mathrm{C}$. The year-to-year variations in air temperature show that the air temperature is rising steadily. Climate variability is also manifested by a spatio-temporal dynamic of annual rains, a recession in the frequency of rainy days and a decrease in the duration of the rainy seasons (from 30 to 35 days). Despite the disruptions of the different seasons of the year, the monthly rainfall patterns have not been changed. We proposed fourteen variables for the normalized principal component analysis which allowed us to analyze the factors of temporal variability of seasonal climatic regimes in the study setting. These variables relate to atmospheric parameters (air temperature and humidity) and precipitation (frequency and amount of precipitation). The normalized principal component analysis allowed the extraction of four principal components, of which the first three were used for the interpretation of the data. The time series constructed from these fourteen variables extend over the period 1968-2000. The normalized principal component analysis based on these different variables has made it possible to highlight the impact of climate variability on seasonal rainfall patterns. The first principal component (F1) is associated with the factors defining the atmospheric conditions. The second and third principal components (F2 and F3) are associated with variables related to precipitation. As for the factors that influence the temporal variability of seasonal rainfall regimes, it appeared that the six rainfall variables are influenced by air temperature as well as relative air humidity. It is therefore concluded that air temperature and relative air humidity are factors in the temporal variability of seasonal rainfall patterns in the study setting.

\section{Compliance with ethical standards}

\section{Acknowledgments}

We thank everyone who contributed to the writing of this manuscript.

\section{Disclosure of conflict of interest}

The writing of this manuscript is without conflict of interest. Each of the authors contributed to the success of this manuscript.

\section{References}

[1] Ardoin BS. Variabilité hydroclimatique et impacts sur les ressources en eau de grands bassins hydrographiques en zone soudano-sahélienne, Thèse de Doctorat, Université de Montpellier II, France. 2004.

[2] Ardoin S, Lubès-Niel H, Servat E, Dezetter A, Boyer JF. « Analyse de la persistance de la sécheresse en Afrique de l'Ouest : caractérisation de la situation de la décennie », IAHS Publication. 1990; 278: 223-228.

[3] Assani A, Tardif S. 2005, "Classification, caractérisation et facteurs de variabilité spatiale des régimes hydrologiques naturels au Québec (Canada). Approche éco-géographique », Revue des Sciences de l'Eau. 2005; 18(2): 247-266.

[4] Descroix L, Nouvelot JF, Estrada J, Lebel T. « Complémentarités et convergences de méthodes de régionalisation des précipitations: application à une région endoréique du Nord-Mexique », Revue des Sciences de l'Eau. 2001; 14(3): 281-305.

[5] Ferry L, L'hote Y, Wesselink A.“Les précipitations dans le Sud-Ouest de Madagascar », IAHS Publication. 1998; 252: 89-96. 
[6] Fontaine B, Janicots S. «L'évolution des idées sur la variabilité interannuelle récente des précipitations en Afrique de l'Ouest », La Météorologie. 1993; 8(1): 28-41.

[7] Goula BTA, Savané I, Konan B, Fadika V, Kouadio GB. « Impact de la variabilité climatique sur les ressources hydriques des bassins de N'zo et N'zi en Côte d'Ivoire (Afrique tropicale humide) », Vertigo. 2006; 1: 1-12.

[8] Houndenou C, Hernandez K. 1998, « Modification de la saison pluvieuse dans l’Atakora (1961-1990). Un exemple de sécheresse au Nord-Ouest du Bénin (Afrique occidentale) », Sécheresse. 1998; 9(1): 23-34.

[9] Hubert P, Servat E, Paturel JE, Kouamé B, Bendjoudi H, Carbonnel JP, Lubès-Niel H. « La procédure de segmentation, dix ans après », IAHS Publication. 1998; 252: 267-273.

[10] Kouassi AM. Caractérisation d'une modification éventuelle de la relation pluie-débit et ses impacts sur les ressources en eau en Afrique de l'Ouest : cas du bassin versant du N'zi (Bandama) en Côte d'Ivoire, Thèse de Doctorat, Université de Cocody-Abidjan, Côte d'Ivoire. 2007.

[11] Kouassi AM, Kouamé KF, Goula BTA, Lasm T, Paturel JE, Biémi J. «Influence de la variabilité climatique et de la modification de l'occupation du sol sur la relation pluie-débit à partir d'une modélisation globale du bassin versant du N'zi (Bandama) en Côte d'Ivoire », Revue Ivoirienne des Sciences et Technologie. 2008; 11: $207-229$.

[12] Laberge C, Cluis D, Saulnier GM. «Analyses directionnelles multivariées de la qualité des précipitations sur la région de Québec », Revue des Sciences de l'Eau. 1994; 7: 269-284.

[13] Lubès-Niel H, Masson JM, Paturel JE, Servat E. «Variabilité climatique et statistiques. Etude par simulation de la puissance et de la robustesse de quelques tests utilisés pour vérifier l'homogénéité de chroniques », Revue des Sciences de l'Eau. 1998; 3: 383-408.

[14] N'guessan KE. 1990, «Etude de l'évolution de la végétation du «V baoulé » (contact forêt/savane en Côte d'Ivoire) par télédétection », in Lafrance P., Dubois J. M., Apports de la télédétection à la lutte conte la sécheresse, Actes des journées scientifiques de Thiès, Edition AUPEL-UREF. 1990.

[15] OMM. «Guide des pratiques climatologiques ». 1990; 100.

[16] Ouédraogo M. Contribution à l'étude de l'impact de la variabilité climatique sur les ressources en eau en Afrique de l'Ouest. Analyse des conséquences d'une sécheresse persistante: normes hydrologiques et modélisation régionale, Thèse de Doctorat, Université de Montpellier II, France. 2001.

[17] Ozer P, Erpicum M. « Méthodologie pour une meilleure représentation spatio-temporelle des fluctuations pluviométriques observées au Niger depuis 1905 », Sécheresse. 1995; 6(1): 103-108.

[18] Paturel JE, Servat E, Kouamé B, Lubès-Niel H, Ouedraogo M, Masson JM. Climatic variability in humid Africa along the Gulfe of Guinea. Part two: an integrated regional approach, Journal de l' Hydrologie. 1997; 191: 16-36.

[19] Paturel JE, Servat E, Delattre MO. « Analyse de séries pluviométriques de longue durée en Afrique de l'Ouest et centrale non sahélienne dans un contexte de variabilité climatique », Journal des Sciences Hydrologiques. 1998; 43(3): 937-945.

[20] Richard Y, Camberlin P, Fauchereau N. « El Nino-la Nina: cohérence intrasaisonnière de la variabilité pluviométrique interannuelle en Afrique du Sud », Espace géographique. 2002; 1: 63-72.

[21] Servat E, Paturel JE, Kouamé B, Lubès-Niel H, Ouedraogo M, Masson JM. 1997, "Climatic variability in humid Africa along the Gulfe of Guinea. Part I: detailed analysis of the phenomenon in Côte d'Ivoire", Journal de l'Hydrologie. 1997; 191: 1-15.

[22] Servat E, Paturel JE, Kouamé B, Travaglio M, Ouédraogo M, Boyer JF, Lubès-Niel H, Fritsch JM, Masson JM, Marieu B. «Identification, caractérisation et conséquences d'une variabilité hydrologique en Afrique de l'Ouest et centrale », IAHS Publication. 1998; 252: 323-337.

[23] Servat E, Paturel JE, Lubès-Niel H, Kouamé B, Masson JM, Travaglio M, Marieu B. « De différents aspects de la variabilité de la pluviométrie en Afrique de l'ouest et centrale non sahélienne », Revue des Sciences de l’Eau. 1992; 12(2): 363-387.

[24] Sultan B, Servat E, Maley J, Mahé G. «Interrelations entre les forêts tropicales et la variabilité climatique : une synthèse des études récentes », Sécheresse. 2012; 12(4): 221-229.

[25] Touaïbia B, Inegliz S, Ould AA. « Couplage d'une analyse en composantes principales et d'une approche géostatistique pour l'élaboration de cartes pluviométriques du Centre de l'Algérie du Nord », Revue des Sciences de l’Eau. 2006; 19(3): 213-219. 